\title{
ERRATUM
}

\section{ERRATUM in Wilderness Environ Med. 29/3}

The author list of a recent article contained a misspelled name.

The published author list (misspelling underlined) was:

Tritz D, Dormire K, Brachtenbach T, Gordon J, Sanders

D, Gearheart D, Crawford J, Vassar M.

The corrected author list (corrected name underlined) is:
Tritz D, Dormire K, Brachtenbach T, Gordon J, Sanders D, Gearhart D, Crawford J, Vassar M.

The corrected article citation is as follows, and will be reflected in the online record of the article:

Tritz D, Dormire K, Brachtenbach T, Gordon J, Sanders D, Gearhart D. Research gaps in wilderness medicine. Wilderness Environ Med. 2018;29(3):291-303. 